Biotechnology for Biofuels

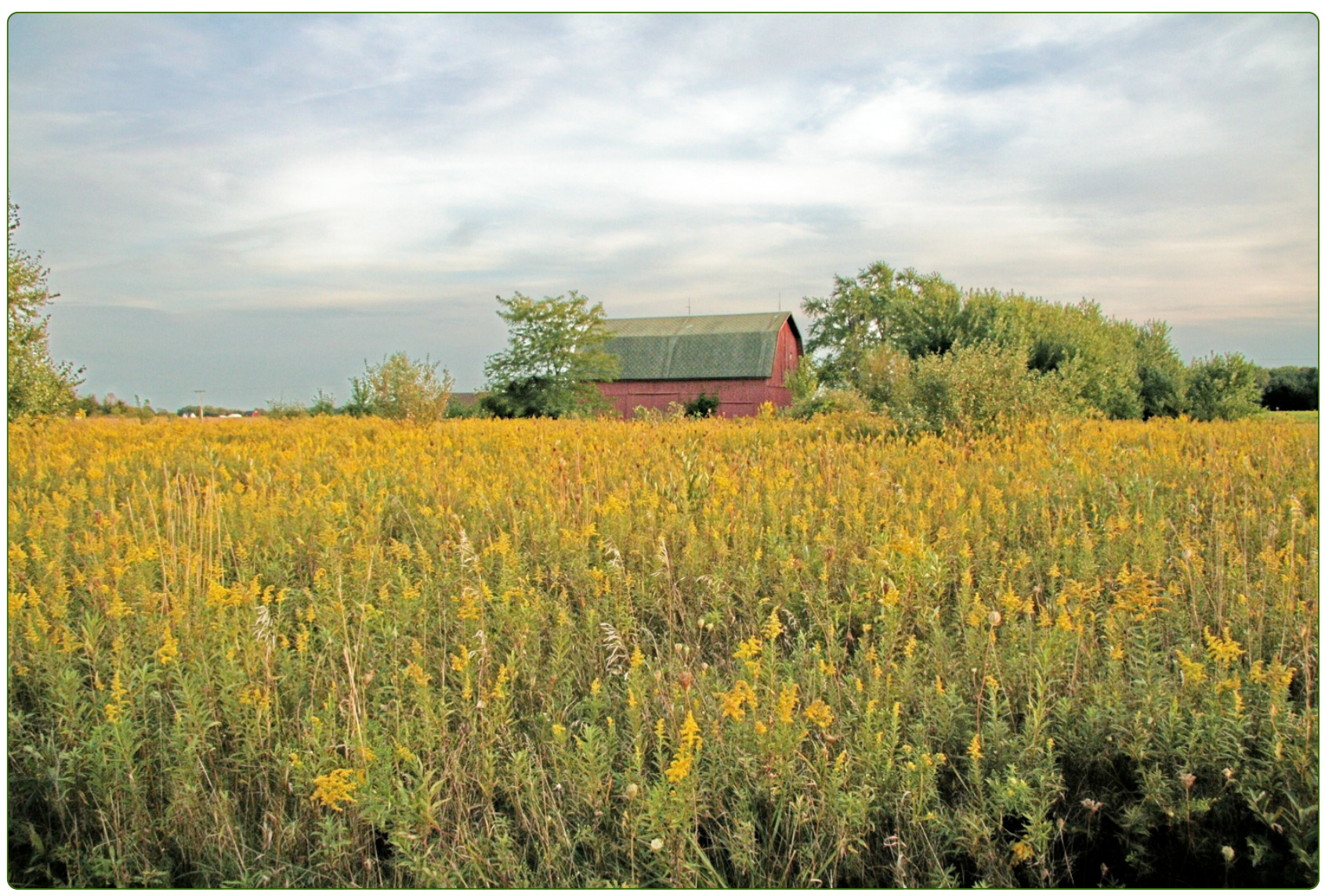

Factors contributing to the recalcitrance of herbaceous dicotyledons (forbs) to enzymatic deconstruction

Jabbour et al.

C Biomed Central 


\title{
Factors contributing to the recalcitrance of herbaceous dicotyledons (forbs) to enzymatic deconstruction
}

\author{
Dina Jabbour ${ }^{1}$, Evan R Angelos ${ }^{1}$, Achira Mukhopadhyay ${ }^{1}$, Alec Womboldt ${ }^{1}$, Melissa S Borrusch ${ }^{1}$ \\ and Jonathan D Walton ${ }^{1,2^{*}}$
}

\begin{abstract}
Background: Many different feedstocks are under consideration for the practical production of biofuels from lignocellulosic materials. The best choice under any particular combination of economic, agronomic, and environmental conditions depends on multiple factors. The use of old fields, restored prairie, or marginal lands to grow biofuel feedstocks offers several potential benefits including minimal agronomic inputs, reduced competition with food production, and high biodiversity. However, a major component of such landscapes is often herbaceous dicotyledonous plants, also known as forbs. The potential and obstacles of using forbs as biofuel feedstocks compared to the more frequently considered grasses and woody plants are poorly understood.

Results: The factors that contribute to the yield of fermentable sugars from four representative forbs were studied in comparison with corn stover. The forbs chosen for the study were lamb's quarters (Chenopodium album), goldenrod (Solidago canadensis), milkweed (Asclepias syriaca), and Queen Anne's lace (Daucus carota). These plants are taxonomically diverse, widely distributed in northern temperate regions including the continental United States, and are weedy but not invasive. All of the forbs had lower total glucose (Glc) content from all sources (cell walls, sucrose, starch, glucosides, and free Glc) compared to corn stover (range 16.2 to $23.0 \%$ on a dry weight basis compared to $39.2 \%$ for corn stover). When digested with commercial enzyme mixtures after alkaline pretreatment, yields of Glc as a percentage of total Glc were lower for the forbs compared to corn stover. Enzyme inhibition by water-extractable compounds was not a significant contributor to the lower yields. Based on experiments with optimized cocktails of pure glycosyl hydrolases, enzyme imbalance probably accounted for much of the lower yields. Addition of xyloglucanase and a-xylosidase, two enzymes targeting Glc-containing polysaccharides that are more abundant in dicotyledonous plants compared to grasses, enhanced Glc yields from lamb's quarters, but Glc yields were still lower than from corn stover.

Conclusion: The potential utilization of forb-rich plant communities as biofuel feedstocks must take into account their lower Glc content compared to grasses such as corn stover. Furthermore, new enzyme mixtures tailored to the different cell wall composition of forbs will have to be developed.
\end{abstract}

Keywords: Milkweed, Goldenrod, Queen Anne's lace, Lamb's quarters, Cellulase, Biofuels, Pretreatment, Alkaline hydrogen peroxide, AFEX

\footnotetext{
* Correspondence: walton@msu.edu

'Department of Energy, Great Lakes Bioenergy Research Center, 1129 Farm

Lane, Michigan State University, East Lansing, MI 48824, USA

${ }^{2}$ Department of Energy, Plant Research Laboratory, 612 Wilson Road,

Michigan State University, East Lansing, MI 48824, USA
} 


\section{Background}

Transportation fuels from lignocellulosic biomass have the potential to contribute to national and regional energy independence, improved economics, and environmental sustainability [1-3]. From the point of view of sustainability, potential biomass feedstocks differ considerably from each other in their requirements for chemical and energy inputs and their positive and negative contributions to environmental health [4]. Conventional monoculture crops are high input and low diversity, whereas feedstocks composed of mixed native or naturalized plants growing with minimal human intervention in either undisturbed or former agricultural land are low input and high diversity. Low-input high-diversity agronomic landscapes include native and restored prairie, marginal lands, and old fields.

A number of studies have addressed the economic and environmental implications of producing biomass for bioenergy from low-input high-diversity landscapes [5-14]. Garlock et al. [7] found that fermentable sugar yields positively correlated with the percent composition of grasses compared to forbs in early successional old field communities comprising 7 to 14 species. This was attributed to both the higher glucan content of grass cell walls and the greater enzymatic conversion efficiency of grass biomass. However, the inherent species complexity of natural plant communities makes it challenging to control for differences between species within the two groups (grasses and forbs) and to elucidate the underlying reasons for the apparent superiority of grasses over forbs. In order to minimize some of the variability innate in mixed communities, we have compared four individual forb species for yields of fermentable sugars, using corn stover (CS) as a benchmark. Factors studied included total glucose (Glc) content, response to pretreatments, presence of enzyme inhibitors, and enzymatic digestibility.

\section{Results}

The four species of forbs used in this study were milkweed (MW) (Asclepias syriaca), Queen Anne's lace (QA) (Daucus carota), lamb's quarters (LQ) (Chenopodium album), and goldenrod (GR) (Solidago canadensis). These species were chosen because they are taxonomically diverse, widely distributed in northern temperate regions including the continental United States, frequent components of old fields and marginal lands, and weedy but not invasive

\section{Composition analysis}

The plant materials were ground but not otherwise treated or washed before compositional analysis (Table 1). Therefore, the analysis includes not just structural (cell wall) sugars but also free sugars, sugar nucleotides, sucrose, starch, and glycosides. This is a more realistic estimate of the actual material that would be encountered in a lignocellulosic ethanol facility than if only the sugars present in structural macromolecules were analyzed. Neutral sugars (Glc, Xyl [xylose], Gal [galactose], Ara [arabinose] + Man [mannose]) comprised $66.8 \%$ of the total dry weight of CS whereas the forbs were very similar to each other, ranging from $35 \%$ to $36.4 \%$. Structural Glc made the greatest contribution to total Glc across all plants, although the forbs did differ from each other in their levels of sucrose, starch, and free Glc. In regard to the content from all sources of Glc, the most valuable fermentable sugar, CS was much higher than any of the forbs (39.2\% versus 16.2 to $23.0 \%$ ).

\section{Pretreatments}

The four forbs were pretreated with dilute acid, ammonia fiber expansion (AFEX), or alkaline hydrogen peroxide (AHP). Four concentrations of acid $\left(\mathrm{H}_{2} \mathrm{SO}_{4}\right)$ and twelve AFEX treatments were compared on goldenrod (GR) alone. Materials were subsequently digested with a 3:1 ratio of Cellic $^{\text {тM }}$ CTec2 plus HTec2 (abbreviated C/ HTec2) at a loading of $30 \mathrm{mg} / \mathrm{g}$ glucan for 96 hours. The acid-treated material was neutralized with $\mathrm{NaOH}$ but not washed after pretreatment. Among acid treatments, the highest concentration tested (1.5\%) gave the best yield, and among AFEX conditions, an ammonia loading of $1.5: 1$ at $100 \%$ moisture $\left(140^{\circ} \mathrm{C}\right)$ for 15 minutes gave the best yields (data not shown). All four forbs were then subjected to these same acid and AFEX conditions,

Table 1 Composition of plant materials

\begin{tabular}{cccccccccc}
\hline & Protein & Glc & Xyl & Gal & Ara + Man & Sucrose & Starch & Free Glc & Total neutral sugars \\
\hline Goldenrod (GR) & $10.3 \pm 1.1$ & $214.5 \pm 2.7$ & $47.4 \pm 0.7$ & $11.7 \pm 2.2$ & $18.3 \pm 0.3$ & $38.3 \pm 2.5$ & $6.0 \pm 1.0$ & $13.8 \pm 1.7$ & 350 \\
Lamb's quarters (LQ) $18.7 \pm 7.3$ & $161.6 \pm 1.7$ & $22.3 \pm 0.3$ & $13.7 \pm 1.1$ & $23.4 \pm 0.6$ & $46.0 \pm 3.6$ & $25.6 \pm 1.1$ & $33.4 \pm 3.5$ & 356 \\
Milkweed (MW) & $12.6 \pm 7.9$ & $201.8 \pm 7.6$ & $26.8 \pm 1.2$ & $21.2 \pm 1.2$ & $14.9 \pm 0.5$ & $67.8 \pm 3.4$ & $10.9 \pm 1.2$ & $24.6 \pm 1.3$ & 368 \\
Queen Anne's lace (QA) & $12.7 \pm 1.2$ & $230.0 \pm 18.6$ & $48.7 \pm 2.0$ & $13.2 \pm 2.0$ & $18.7 \pm 0.5$ & $31.2 \pm 4.0$ & $4.5 \pm 1.3$ & $17.6 \pm 1.5$ & 364 \\
Corn stover $^{\mathrm{a}}$ (CS) & $4.0 \pm 0.7$ & $391.5 \pm 0.4$ & $194.7 \pm 10.9$ & $9.4 \pm 2.3$ & $33.3 \pm 5.3$ & $11.5 \pm 0.4$ & $11.8 \pm 0.8$ & $16.0 \pm 1.8$ & 668 \\
\hline
\end{tabular}

${ }^{\mathrm{a}} \mathrm{CS}$ data are from $[19,23]$.

${ }^{\mathrm{b}}$ The HPLC method did not resolve Ara and Man.

Materials were dried but unwashed before analysis, and therefore the values include contributions from non-cell wall components such as starch, glycosides, sucrose, and free Glc. All values are $\mathrm{mg} / \mathrm{g}$ dry weight $\pm 1 \mathrm{SD}(\mathrm{n}=3)$.

Ara, arabinose; Gal, galactose; Glc, glucose; Man, mannose; Xyl, xylose. 
plus alkaline hydrogen peroxide (AHP), and then digested with three loadings of $\mathrm{C} / \mathrm{HTec} 2$ and one loading of Accellerase $^{\text {Ts }}$ 1000Averaged across all enzyme loadings and plants, AHP performed better than acid, which performed better than AFEX. Compared across enzyme loadings, AFEX performed the best on GR followed closely by AHP, acid performed the best on MW, and AHP performed the best on LQ and QA (Figure 1). Due to its overall good performance and ease of execution (it is performed at room temperature and atmospheric pressure in inexpensive containers) [15,16], AHP-pretreated material was used in subsequent experiments.

\section{Enzymatic hydrolysis}

In the initial enzymatic hydrolysis experiment, total biomass loading was kept constant at $3 \mathrm{mg} / \mathrm{ml}$. The Glc yield from CS was $1.17 \mathrm{mg} \mathrm{Glc} / \mathrm{ml}$ (Figure 2), which is about 91\% of the maximal possible. The Glc yields from the forbs species were considerably lower, with the maximum yields from GR, LQ, QA, and MW being $0.54 \mathrm{mg} / \mathrm{ml}$, $0.64 \mathrm{mg} / \mathrm{ml}, 0.58 \mathrm{mg} / \mathrm{ml}$, and $0.59 \mathrm{mg} / \mathrm{ml}$, respectively (Figure 2).

Enzymatic hydrolysis was then compared on an equal glucan loading (Figure 3). After 48 hours of hydrolysis, apparent Glc yields from CS were more than 100\%. This apparent yield of $>100 \%$ was probably due to a combination of factors, including experimental error in the measurement of Glc content and of Glc yields, and Glc contributed by the enzyme cocktail. Wolfrum et al. [17] reported a similar $>100 \%$ yield and discussed other possible explanations. Of the forb species, LQ was the most digestible, achieving $74 \%$ conversion with the highest $\mathrm{C} / \mathrm{HTec} 2$ loading (30 $\mathrm{mg} / \mathrm{gm}$ glucan). At a $\mathrm{C} / \mathrm{HTec} 2$ loading of $15 \mathrm{mg} /$ gmglucan, Glc yields from LQ, GR, QA, and MW were $65 \%, 29 \%, 55 \%$, and $54 \%$ of maximal, respectively. That is, even adjusting for differences in Glc content, yields of Glc from the forbs were low compared to $\mathrm{CS}$.

\section{Preparation and analysis of extractives}

Pretreatment of lignocellulosic material results in the formation and/or release of a number of substances inhibitory to enzymes and fermentative microorganisms [18]. As one possible explanation for the lower yields of Glc from the forbs compared to the CS, even when adjusted for their lower Glc content, we examined the possibility that the forbs contain soluble inhibitors of enzymes. Lowmolecular weight materials, known as extractives, were prepared by washing the plant materials sequentially with water, ethanol, and acetone. The extractives were tested at equal relative concentrations for their effects on the digestibility of CS. Extractives prepared in the same way from CS were used as a control. The extractives contained significant amounts of Glc in both free and polymeric
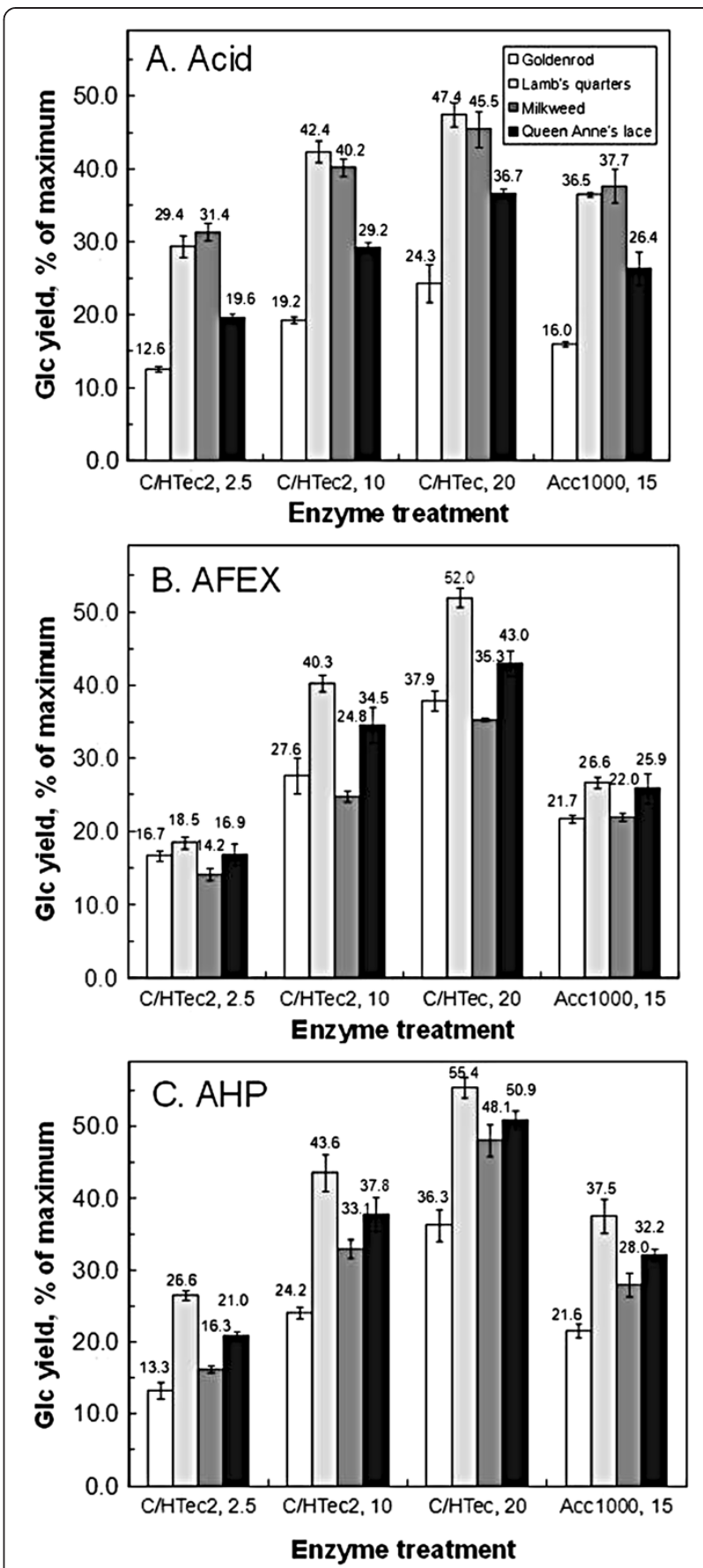

Figure 1 Comparison of three pretreatments on subsequent enzyme hydrolysis of four species of forbs. A. Dilute acid. B. AFEX. C. AHP. C/HTec2 refers to a 3:1 mixture of Cellic ${ }^{\text {TM }} \mathrm{CTec} 2$ and $\mathrm{HTec2}$. Acc1000 is Accellerase 1000. Numbers after the enzyme names indicate the loadings in $\mathrm{mg}$ protein/gm glucan. Biomass loading was $2 \mathrm{mg}$ glucan $/ \mathrm{ml}$, incubation temperature was $50^{\circ} \mathrm{C}$, and incubation time was 48 hours. AFEX, ammonia fiber expansion; AHP, alkaline hydrogen peroxide; Glc, total glucose.

form, which were subtracted from total Glc yields to calculate the yields from enzymatic digestion of the polymeric, insoluble glucans alone. 


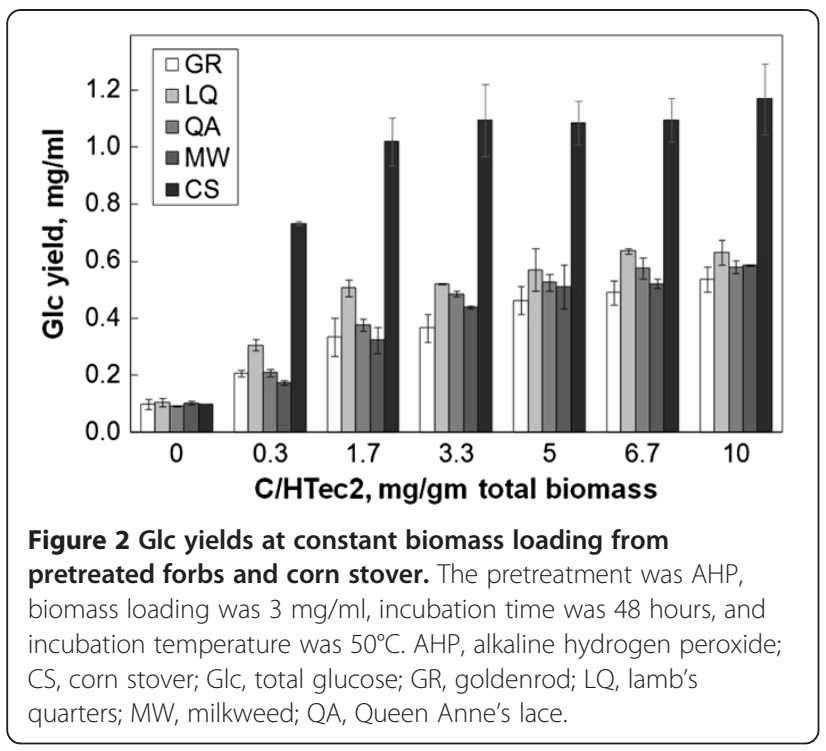

Comparison of the yields of Glc from CS in the presence of inhibitors, compared to CS alone or CS + extractives from corn, indicated that forbs extractives caused some inhibition (indicated by the relative heights of the black bars in Figure 4). Soluble extracts of CS inhibited yields of Glc from CS by $16.2 \%$. GR extracts were the most inhibitory (29.1\% inhibition). The other forbs were intermediate, LQ and MW being less inhibitory than CS and QA slightly more inhibitory (Figure 4).

Optimization of synthetic 8-component enzyme mixtures Even taking into account the lower Glc content of the forbs and the slight inhibition by their soluble components, yields of Glc from the forbs were still lower than

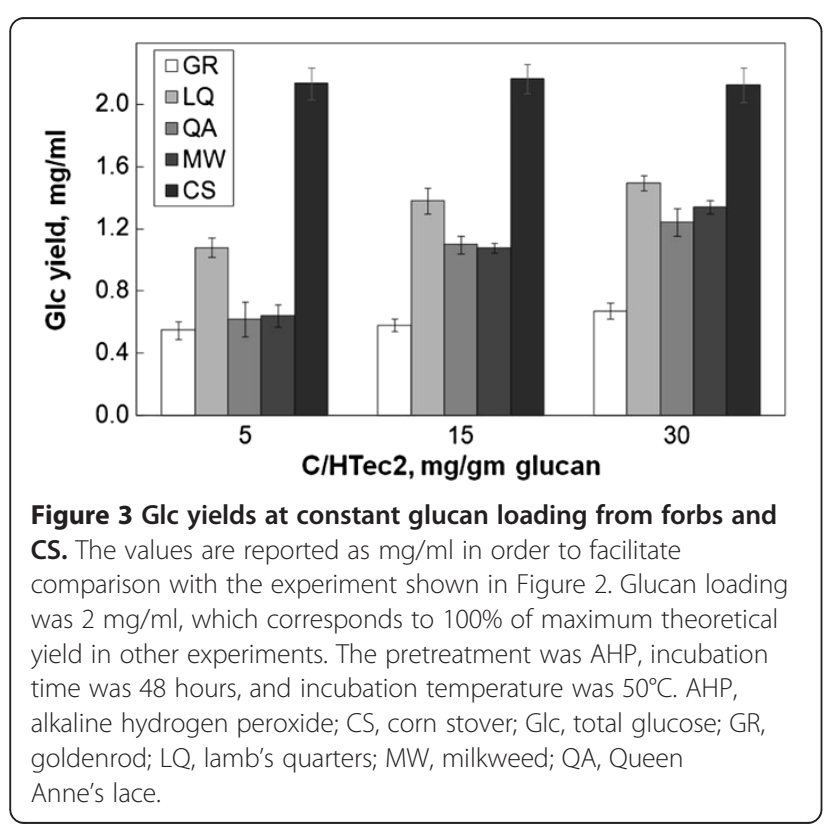

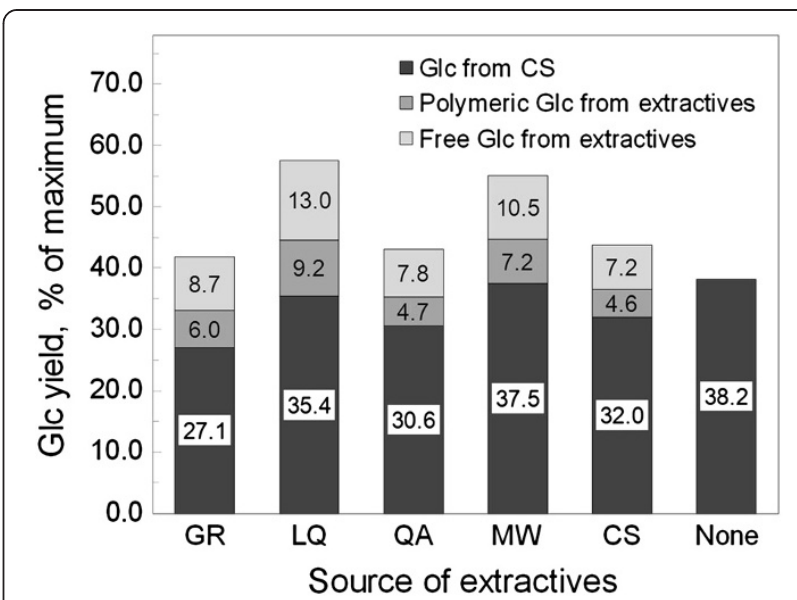

Figure 4 Effect of extractives from forbs on enzymatic deconstruction of CS. Water and solvent-soluble materials were extracted from the indicated forbs or from CS. The total heights of the bars indicate the total Glc measured in each sample following enzymatic digestion of each CS sample by $\mathrm{C} / \mathrm{HTec} 2$, added at $10 \mathrm{mg} / \mathrm{g}$ glucan for 48 hours at $50^{\circ} \mathrm{C}$. The different shadings indicate the amount of Glc originating from free Glc that was present in the extractives added to each reaction (light bars), the Glc released by the enzymes due to the enzymatic digestion of the CS biomass (black bars), and the Glc released upon digestion of soluble biomass components that were present in the extractives added to the reactions (medium grey bars). Reduction of polymeric Glc yields from the CS (black bars) compared to the no-extractives control (38.2\% Glc yield) indicates the degree of enzyme inhibition by the extractives from each plant species. The differences in digestibility of GR, $\mathrm{QA}$, and CS were significantly different from the CS alone at $P<0.05$. $A H P$, alkaline hydrogen peroxide; $C S$, corn stover; Glc, total glucose; GR, goldenrod; LQ, lamb's quarters; MW, milkweed; QA, Queen Anne's lace.

from CS. A possible explanation for this is that the enzymes found in $\mathrm{C} / \mathrm{HTec} 2$ are inappropriate in content or in proportions for the digestion of the cell walls of herbaceous dicotyledonous plants. To test this, enzyme optimization experiments were performed. Synthetic mixtures of eight 'core' enzymes (BG, EG1, CBH1, CBH2, GH61, BX, EX2 and EX3) were optimized [19,20]. A minimum proportion of $5 \%$ was set as a lower limit for all enzymes.

In the case of CS, the following proportions of an 8component synthetic enzyme mixture resulted in the highest Glc yield of approximately $75 \%$ after 48 hours: 30\% CBH1, 20\% EG1, 20\% GH61, 5\% BG, 5\% CBH2, 5\% $\mathrm{BX}, 5 \% \mathrm{EX} 2$, and $10 \% \mathrm{EX} 3$. The resulting model was statistically significant. In the case of the forbs, under the same experimental design conditions, Glc yields never exceeded approximately 20 to $30 \%$ at any enzyme combination, and as a result no statistically significant model of optimized proportions could be determined (data not shown). Apparently, although $\mathrm{C} / \mathrm{HTec} 2$ is suitable for reasonable yields from forbs as well as CS, mixtures containing only these eight enzymes in any proportions are insufficient for the hydrolysis of forbs. Other enzymes, 
which are present at least in part in $\mathrm{C} / \mathrm{HTec} 2$, are necessary for hydrolysis of the cell walls of herbaceous dicotyledons.

\section{Accessory enzymes}

$\mathrm{C} / \mathrm{HTec} 2$ could release more than $75 \%$ of the Glc from some forbs (Figure 3), but the optimized 8-component could not release more than $30 \%$. One possible explanation for this result is that forbs, but not CS, require additional accessory enzymes that are present in $\mathrm{C} / \mathrm{HTec} 2$ but not in the 8-component mixture. In an attempt to identify what these hypothetical enzymes might be, additional accessory enzymes were tested by supplementation of the 8-component mixture. As dicotyledonous plants contain more pectin than cereal cell walls, and modification of pectin composition has been shown to enhance Glc release [21], supplementation with Multifect ${ }^{\mathrm{TM}}$ Pecti- $^{-}$ nase was first tested. Multifect ${ }^{\mathrm{TM}}$ Pectinase, derived from Aspergillus niger, contains more than 130 proteins including numerous pectinases of diverse specificities [22]. However, in no experiment did Multifect ${ }^{\mathrm{TM}}$ Pectinase enhance either Glc or Xyl yields from any of the forbs, either in combination with the 8-component mixture or in combination with $\mathrm{C} / \mathrm{HTec} 2$ (data not shown).

Supplementation of the 8-component mixture with individual enzymes was also attempted. All of the pure enzymes were from Trichoderma reesei and expressed in Pichia pastoris, except AxlA, which was expressed in $P$. pastoris from an A. niger gene [22,23]. LQ was used as the substrate at a loading of $2 \mathrm{mg}$ glucan $/ \mathrm{ml}$. Supplementation of an 8-component mixture (in the proportions shown to be optimal for CS) with $5 \mathrm{mg} / \mathrm{gm}$ glucan of Abf1, Abf2, AbfB, Cip 1, Cip2, GH12, or $\beta$-galactosidase did not enhance Glc yields from LQ, but supplementation with xyloglucanase (XG,Cel74A) and $\alpha$-xylosidase (AxlA) did enhance yields (Table 1 and Figure 5). AxlA had earlier been shown to enhance Glc yields from LQ in combination with $\mathrm{C} / \mathrm{HTec} 2$ [23]. Supplementation of the 8-component mixture with both AxlA and XG increased yields of Glc by $12.2 \%$, and further addition of $\beta$-galactosidase or AbfB had no effect (Figure 5). These results indicate that one of the enzymes present in $\mathrm{C} / \mathrm{HTec} 2$ that is important for Glc release from forbs is XG $(\mathrm{C} / \mathrm{HTec} 2$ lacks AxlA or $\alpha$-xylosidase activity), but that there are probably others.

\section{Discussion}

There have been relatively few studies exploring the potential utility of herbaceous dicotyledons (forbs) for the production of lignocellulosic biofuels. Past studies have either looked at dicotyledonous crop residues (such as straw from sunflower, soybean, alfalfa, canola, and cotton), or forbs in the context of mixed communities predominantly containing grasses [7,24-31]. To survey the

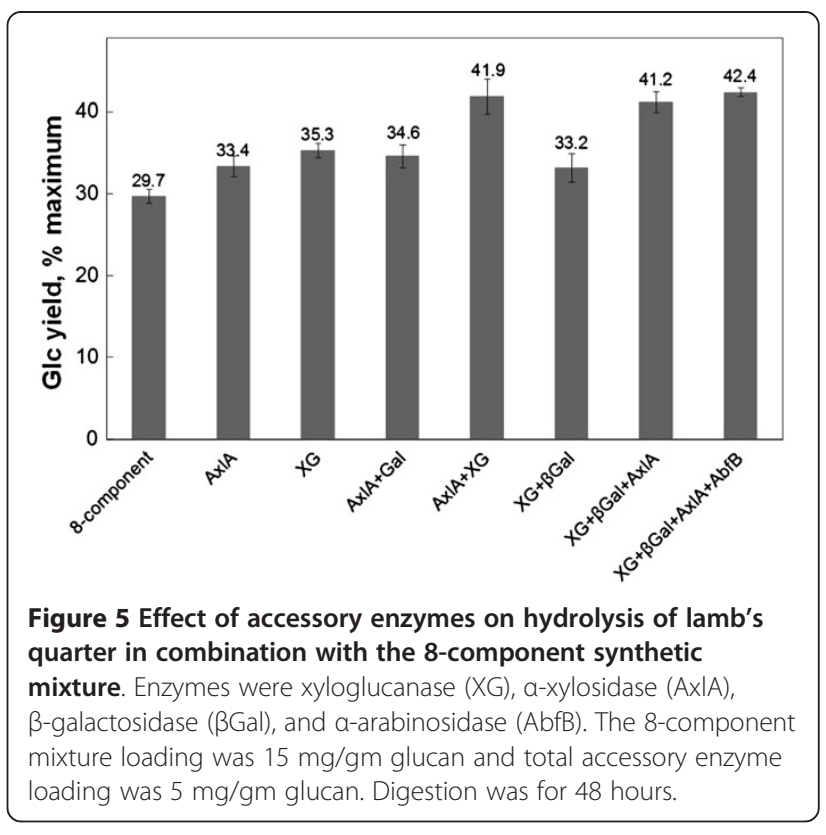

potential of forbs that are likely to be found in northern temperate mixed plant communities such as old fields and marginal lands, and to reduce the complexity of working with a mixture of species, we explored the factors affecting Glc yields from four single species of forbs. CS, a widely used lignocellulosic feedstock, served as a benchmark. The factors considered were sensitivity to pretreatments, content of neutral sugars, presence of enzyme inhibitors, and enzymatic digestibility. We found that yields of Glc from all forbs were consistently much lower than from CS, and that two factors dominated the recalcitrance of forbs: lower Glc content and enzyme imbalance. Our study did not address the possible importance of either lignin content or lignin structure, both of which are known to differ between dicotyledons and grasses [32,33]. The four forbs showed similar trends in regard to glucan content and digestibility even though they were taxonomically diverse, and therefore it should be possible to extrapolate from the results in this paper to other herbaceous dicotyledons.

In regard to the lower Glc content in our experiments, this was probably in part due to the harvest time of the forbs. CS as a lignocellulosic biomass is still a secondary crop to the more valuable grain, and is therefore harvested after the translocatable nutrients in the leaves have been mobilized into the grain. On the other hand, the forbs used in the current work were harvested midseason when they were still actively growing, and therefore were richer in non-structural constituents such as chlorophyll, primary metabolites, and protein. This is evidenced by the protein and soluble sugar content of the forbs compared to CS (Table 1). If the forbs had been harvested in the late autumn, they may have had lower 
protein and other cytoplasmic contents, and a higher structural polysaccharide content [26].

Determining when might be the best time to harvest forbs for bioethanol production remains to be established. Younger plants tend to have a lower lignin content, which is positively correlated with enhanced enzyme digestibility, but younger plants are also smaller and their higher mineral nutrient content compared to senescent plants would result in greater loss of soil nutrients from the harvested fields. Various agronomic practices have been envisioned for optimal harvesting of forb-rich landscapes such as marginal lands, restored prairie, and old fields. These include harvesting once every few years, once in midseason, once in late autumn, or multiple times throughout the season, and the best choice is dependent on multiple factors [13,24]. Furthermore, agronomic optimization would probably be different for different forbs. For example, because GR and MW are perennials and therefore regrow from the roots each year, a harvest date after the nutrients have been mobilized into the roots would be preferable. On the other hand, if an annual such as LQ were harvested midseason before it sets seed, it could not selfpropagate the following season. Yet a different harvest strategy might be preferred for biennials such as QA. In a real-world situation, for example, old fields containing a variety of species, harvest time would have to be a compromise between these factors.

In regard to susceptibility to enzyme digestion, our results indicated that current commercial enzymes are maladapted to forbs. This is not surprising in light of the known differences in cell wall structure between forbs and grasses, and the fact that recent efforts on commercial enzyme improvement have focused on acid-treated CS as the preferred substrate [34].

We had previously developed a mixture of eight purified cell-wall degrading enzymes that could reasonably match commercial enzyme mixtures $[19,20]$. However, no combination of the same core enzymes was effective on forbs. In an attempt to rectify the poor behavior of the 8-component mixture, additional enzymes were tested. Ax1A, an enzyme lacking in T. reesei [22], and XG (Cel74A) together increased Glc yields from GR from $29.7 \%$ to $41.9 \%$, which is consistent with the known higher levels of xyloglucan in dicotyledons compared to grasses. This result suggests that there is promise for developing enzyme mixtures adapted to forbs, but also indicates that additional, unknown enzymes will be required to match the performance of commercial mixtures, such as $\mathrm{C} / \mathrm{HTec} 2$, on $\mathrm{CS}$.

\section{Conclusions}

As naturally occurring, low-input plants, forbs offer distinct advantages as a source of biomass for conversion to biofuels. However, their effective use will require accomodation for their particular properties, which include lower Glc content and poor response to existing enzyme cocktails.

\section{Methods}

\section{Plant materials, harvest, and preparation}

Samples of CS (Zea mays Pioneer hybrid 36H56), harvested in the autumn after drydown, was provided by the Great Lakes Bioenergy research center (GLBRC). Samples of MW, QA, and LQ were collected locally from roadsides and abandoned farmland in mid-August, 2010. A sample of GR was obtained from an old field near Kellogg Biological Field Station, Hickory Corners, MI, United States. All above-ground parts of the plants were used.

The plant materials were dried at $50^{\circ} \mathrm{C}$ for 48 hours and ground with a Christy \& Norris 8-inch Lab Mill with a 1-mm screen (Christy-Turner Ltd., Suffolk, United Kingdom). The material was further ground in a Wiley mill (Thomas Scientific, Swedesboro, NJ, United States) to pass through a $0.5 \mathrm{~mm}$ screen. All of the starting material was processed through the mill; no material was discarded. Ground samples were stored in sealed containers at room temperature.

\section{Pretreatments}

For dilute acid pretreatment, $\mathrm{H}_{2} \mathrm{SO}_{4}$ concentrations were $0,0.2,0.6$, and $1.5 \%(\mathrm{v} / \mathrm{v})$. Samples were autoclaved in the acid at $121^{\circ} \mathrm{C}$ for 30 minutes, cooled, neutralized with $\mathrm{NaOH}$, and lyophilized. Twelve AFEX conditions were compared, with ammonia loadings of 1:1, 1.5:1, or $2: 1$; moisture contents of $60 \%, 100 \%$, or $150 \%$; temperatures of $90^{\circ} \mathrm{C}$ or $140^{\circ} \mathrm{C}$; and times of 15 or 30 minutes [35].

For AHP pretreatment, a solution of $\mathrm{H}_{2} \mathrm{O}_{2}$ diluted from a 30\% stock solution (J.T. Baker, ACS Reagent Grade, Fisher Scientific, Pittsburgh, PA, United States) was titrated to $\mathrm{pH} 11.5$ with $5 \mathrm{M} \mathrm{NaOH}$ and then mixed with the biomass in a ratio of $0.25 \mathrm{~g} \mathrm{H}_{2} \mathrm{O}_{2} / \mathrm{g}$ biomass. Samples were pretreated for 72 hours at room temperature $\left(21^{\circ} \mathrm{C}\right)$ with rotary shaking at $90 \mathrm{rpm}$. After pretreatment, the $\mathrm{pH}$ of the suspension was adjusted to 7.0 with concentrated $\mathrm{HCl}$, treated with catalase to break down residual $\mathrm{H}_{2} \mathrm{O}_{2}$, heated to $90^{\circ} \mathrm{C}$ for 15 minutes to inactivate the catalase, and lyophilized $[15,16]$. Because the samples were not washed after pretreatment, the glucan content used for calculating enzyme loadings were adjusted for the weight of the salts resulting from the dilute acid and AHP pretreatments and neutralizations.

\section{Compositional analysis}

Dried, ground, unwashed biomass was subjected to a twostep hydrolysis with sulfuric acid and the sugars quantitated by HPLC using an SP0180 column (Showa-Denko America, Inc., NY, United States) at $85^{\circ} \mathrm{C}$ with water as 
mobile phase [36]. This method resolved Glc, Xyl, and Gal, but not Ara and Man from each other. Because the biomass was not washed, the total Glc content included contributions not just from structural polysaccharides but also free Glc, sucrose, glucosides, and starch. Free Glc, sucrose, and starch before acid hydrolysis were assayed as described [37].

The protein content of the plant materials was measured by suspending $100 \mathrm{mg}$ of unwashed biomass in $1.5 \mathrm{ml}$ water and mixing for 1 hour. After centrifugation, the supernatants were assayed for total protein by the method of Bradford [38] with bovine immunoglobulin as the standard.

\section{Enzymatic hydrolysis}

Biomass substrates were suspended at a concentration of $2 \mathrm{mg}$ glucan $/ \mathrm{ml}$ in $50 \mathrm{mM}$ sodium citrate buffer, $\mathrm{pH}$ 5.0, plus cycloheximide and tetracycline each at $10 \mu \mathrm{g} / \mathrm{ml}$. Cellic $^{\mathrm{Tu}}$ CTec2 and HTec2 enzymes (a gift of Novozymes, Davis, CA, United States)lot numbers VCPI0004 and VHN00002, respectively) were used at a protein mass ratio of 3:1. In this paper, this mixture of $\mathrm{CTec} 2$ and $\mathrm{HTec} 2$ is abbreviated $\mathrm{C} / \mathrm{HTec} 2$. The protein concentrations of CTec2 and HTec2 were taken as $130 \mathrm{mg} / \mathrm{ml}$ and $101 \mathrm{mg} / \mathrm{ml}$, respectively [38]. Accellerase ${ }^{\mathrm{mm}} 1000$ was a gift of Genencor/DuPont, Palo Alto, CA, United States) (lot number 1600844643; $69 \mathrm{mg}$ protein/ml). Multifect ${ }^{\mathrm{tm}}$ Pectinase was a generous gift of Dupont/Danisco (Rochester, NY, United States). Digestion assays were performed in 96 deep-well plates at $50^{\circ} \mathrm{C}$ in a rotary incubator at $10 \mathrm{rpm}$ for 72 hours with sampling every 24 hours [19]. Each reaction volume was $0.5 \mathrm{ml}$. Released Glc was measured colorimetrically with a glucose oxidase-peroxidase (GOPOD) reagent (Megazyme, Bray, Ireland). Assays were run in duplicate, sampled twice, and the Glc levels measured twice. Therefore, each data point represents the mean of eight values. Error bars represent $+/$-one standard deviation (SD) of the mean.

\section{Preparation and assay of extractives}

Pretreated but unwashed biomass (equivalent to $1 \mathrm{~g}$ glucan according to Table 2) was washed sequentially with $20 \mathrm{ml}$ of water, $20 \mathrm{ml}$ ethanol, and $20 \mathrm{ml}$ acetone on a Buchner funnel through Whatman \#1 filter paper (GE Life Sciences, Piscataway, NJ, United States). The resulting extracted material solutions were dried at $50^{\circ} \mathrm{C}$ overnight and redissolved in $10 \mathrm{ml}$ water. Glc content in the extractives was assayed directly as described above. The extractives were then digested to completion with $\mathrm{C} / \mathrm{HTec} 2$ and re-measured for free Glc. The difference before and after enzymatic digestion was taken as Glc due to soluble oligosaccharides, with a small contribution from the $\mathrm{C} / \mathrm{HTec} 2$ itself, which was subtracted.
Table 2 Effect of accessory enzymes on release of Glc from AHP-pretreated LQ by the 8-component synthetic enzyme mixture

\begin{tabular}{lc}
\hline & Glc yield, \% of maximum \\
\hline 8-component alone & $29.66 \pm 0.74$ \\
+ Cip1 & $23.35 \pm 3.15$ \\
+ Cip2 & $29.68 \pm 0.03$ \\
+ Abf1 & $29.86 \pm 0.51$ \\
+ Abf2 & $29.95 \pm 0.28$ \\
+ AbfB & $29.83 \pm 0.69$ \\
+ XG & $35.33 \pm 0.34$ \\
+ GH12 & $27.48 \pm 0.38$ \\
$+\beta$-galactosidase & $30.02 \pm 1.76$ \\
\hline
\end{tabular}

Values are the means $\pm 1 S D, n=3$. The 8-component mixture was used at $15 \mathrm{mg} / \mathrm{gm}$ glucan and each accessory enzyme was added at $5 \mathrm{mg} / \mathrm{gm}$ glucan. Abf1, arabinosidase 1; Abf2, arabinosidase 2; AbfB, arabinosidase B; AHP, alkaline hydrogen peroxide; Cip1, cellulose-inducible protein 1; Cip2, cellulose-inducible protein 2; GH12, Cel12A; Glc, total glucose; LQ, lamb's quarter; XG, xyloglucanase.

See Materials and Methods for the GenBank or JGI accession numbers.

Enzyme inhibition by the extractives was tested in a standardized assay containing CS at a concentration of $2 \mathrm{mg}$ glucan $/ \mathrm{ml}$ and a C/HTec2 loading of $1 \mathrm{mg} / \mathrm{g}$ glucan, as described below. Extractives derived from the equivalent of $1 \mathrm{mg}$ glucan from unwashed biomass were tested per mg of glucan from corn stover.

\section{Optimization of synthetic 8-component enzyme mixtures}

The $T$. reesei proteins used in the assays were produced by expression in $P$. pastoris as described, except for CBH1 (Cel7A), which was purchased from Megazyme (Bray, Ireland) [19,20]. The enzymes were concentrated and desalted but not otherwise purified. The DOE Joint Genome Institute (JGI) identifiers for the T. reesei proteins, and their alternate names and abbreviations, are CBH1 (cellobiohydrolase 1, Cel7A) [Tr_123989]; EG1 (endoglucanase, Cel7B) [Tr_122081]; CBH2 (Cel6A) [Tr_72567]; BG ( $\beta$-glucosidase, Cel3) [Tr_76672]; EX2 (endo- $\beta 1,4-x y l a n a s e ~ 2$, Cel11) [Tr_123818]; EX3 (endo$\beta 1,4$-xylanase 3, Cel10) [Tr_120229]; BX ( $\beta$-xylosidase, Cel3A) [Tr_121127]; GH61 (Cel61A) [Tr_73643]. DesignExpert $^{\mathrm{mm}}$ software (Stat-Ease, Inc., Minneapolis, MN, United States) and the GLBRC Enzyme Platform (GENPLAT) were used for experimental design, analysis, and optimization of mixtures [19,20]. Enzyme hydrolysis was performed as described above. Per $500 \mu \mathrm{l}$ assay, final glucan loading was $1 \mathrm{mg}$ and enzyme loading was $15 \mu \mathrm{g}$.

\section{Accessory enzymes}

Additional accessory enzymes were tested with the 8component enzyme mixture at a final glucan loading of $1 \mathrm{mg}$ and total enzyme loading of $20 \mathrm{mg} / \mathrm{g}$ glucan in 
$500 \mu \mathrm{l}$ reactions. The accessory enzymes and their JGI identifier numberswere Abf1 ( $\alpha$-arabinosidase 1) [Tr_123279]; Abf2 ( $\alpha$-arabinosidase 2) [Tr 76210$]$; AbfB ( $\alpha$-arabinosidase b) [Tr_123283]; XG (xyloglucanase, Cel74A) [Tr_49081]; $\beta$-galactosidase, Cel35 [Tr_80240]; Cip1 [Tr_73638]; Cip2 [Tr_123940]; Cel12A (endoglucanase) [Tr_123232]. AxlA ( $\alpha$-xylosidase, Cel31) GenBank accession number [BK008484] from $A$. niger was produced by expression in P. pastoris [22,23].

\section{Abbreviations}

AFEX: ammonia fiber expansion; AHP: alkaline hydrogen peroxide; C/HTec2: a 3:1 protein mass mixture of $\mathrm{Cellic}^{\mathrm{TM}} \mathrm{CTec} 2$ and HTec2; CS: corn stover: Glc: glucose; Xyl: xylose; GR: goldenrod; LQ: lamb's quarters; MW: milkweed; QA: Queen Anne's lace.

\section{Competing interests}

The authors declare that they have no competing interests.

\section{Authors' contributions}

DJ, ERA, AM, AW, JDW, and MSB made substantial contributions to the conception and design of the work, acquisition of data, and contributed to writing the manuscript. All authors read and approved the final manuscript.

\section{Acknowledgements}

This work was funded by the US Department of Energy Great Lakes Bioenergy Research Center (GLBRC) (DOE Office of Science BER DE-FC02-07ER64494) and by grant DE-FG02-91ER200021 to the MSU-Plant Research Laboratory from the US Department of Energy, Office of Basic Energy Sciences, Division of Chemical Sciences, Geosciences and Biosciences. Evan Angelos (Kalamazoo College, Michigan) and Alec Womboldt (Manchester University, Indiana) were supported by the GLBRC Summer Experience for Undergraduates (SEU) program. We thank Nick Santoro (GLBRC, MSU) for the starch, sucrose, and Glc analyses and Venkatash Balan (laboratory of Bruce Dale, MSU) for the AFEX treatments. Goldenrod was supplied by Phil Robertson and Poonam Jasrotia of the MSU Kellogg Biological Station and Great Lakes Bioenergy Research Center. Cellic ${ }^{\mathrm{TM}}$ CTec2 and HTec2 were a kind gift of Novozymes (Davis, CA). We thank Dr Rebecca Garlock Ong (Michigan State University) for many valuable comments on the manuscript. The cover photograph was taken by Wanessa Wight.

Received: 25 October 2013 Accepted: 27 March 2014

Published: 5 April 2014

\section{References}

1. Carroll A, Somerville C: Cellulosic biofuels. Annu Rev Plant Biol 2009, 60:165-182

2. Robertson GP, Dale VH, Doering OC, Hamburg SP, Melillo JM, Wander MM, Parton WJ, Adler PR, Barney JN, Cruse RM, Duke CS, Fearnside PM, Follett RF, Gibbs HK, Goldemberg J, Mladenoff DJ, Ojima D, Palmer MW, Sharpley A, Wallace $L$, Weathers KC, Wiens JA, Wilhelm WW: Sustainable biofuels redux. Science 2008, 322:49-50

3. Tilman D, Scolow R, Foley JA, Hill J, Larson E, Lynd L, Pacala S, Reilly J, Searchinger T, Somerville C, Williams R: Beneficial biofuels - The food, energy, and environment trilemma. Science 2009, 325:270-271.

4. Landis DA, Gardiner MM, van der Werf W, Swinton SM: Increasing corn for biofuel production reduces biocontrol services in agricultural landscapes. Proc Natl Acad Sci 2008, 105:20552-20557.

5. Davis SC, Anderson-Teixeira KJ, Delucia EH: Life-cycle analysis and the ecology of biofuels. Trends Plant Sci 2009, 14:140-146.

6. Fischer $G$, Prieler $S$, van Velthuizen $H T$ : Biofuel production potentials in Europe: sustainable use of surplus cultivated land and pastures part II: land use scenarios. Biomass Bioenergy 2010, 34:173-187.

7. Garlock RJ, Bals B, Jasrotia P, Balan V, Dale BE: Influence of variable species composition on the saccharification of AFEX pretreated biomass from unmanaged fields in comparison to corn stover. Biomass Bioenergy 2012, 37:49-59.

8. Gelfand I, Zenone T, Jasrotia P, Jiquan Chen J, Hamilton SK, Robertson GP: Carbon debt of Conservation Reserve Program (CRP) grasslands converted to bioenergy production. Proc Natl Acad Sci USA 2011, 108:13864-13869.

9. Gelfand I, Sahajpal R, Zhang X, Izaurralde RC, Gross KL, Robertson GP Sustainable bioenergy production from marginal lands in the US Midwest. Nature 2013, 93:514-517.

10. James LA, Swinton SM, Thelen KD: Profitability analysis of cellulosic energy crops compared to corn. Agron J 2010, 102:675-687.

11. Jarchow ME, Liebman M, Rawat V, Anex RP: Functional group and fertilization affect the composition and bioenergy yields of prairie plants. GCB Bioenergy 2012, 4:671-679.

12. Meehan TD, Hurlbert AH, Gratton C: Bird communities in future bioenergy landscapes of the Upper Midwest. Proc Natl Acad Sci USA 2010, 43:18533-18538

13. Tilman D, Hill J, Lehman C: Carbon-negative biofuels from low-input high-diversity grassland biomass. Science 2006, 314:1598-1600.

14. Wiens J, Fargione J, Hill J: Biofuels and biodiversity. Ecol App/ 2011, 21:1085-1095

15. Banerjee G, Car S, Liu T, Williams DL, Meza SL, Walton JD, Hodge DB Scale-up and integration of alkaline hydrogen peroxide pretreatment, enzymatic hydrolysis, and ethanolic fermentation. Biotechnol Bioeng 2012, 109:922-931.

16. Banerjee G, Car S, Scott-Craig JS, Hodge D, Walton JD: Alkaline peroxide pretreatment of corn stover: effects of biomass, peroxide and enzyme loading and composition on yields of glucose and xylose. Biotechnol Biofuels 2011, 4:16.

17. Wolfrum EJ, Ness RM, Nagle NJ, Peterson DJ, Scarlata CH: A laboratory-scale pretreatment and hydolysis assay for determination of reactivity in cellulosic biomass feedstocks. Biotechnol Biofuels 2013, 6:162

18. Cao G, Ximenes E, Nichols NN, Zhang L, Ladisch M: Biological abatement of cellulase inhibitors. Bioresour Technol 2013, 146:604-610.

19. Banerjee G, Car S, Scott-Craig JS, Borrusch MS, Bongers M, Walton JD: Synthetic multi-component enzyme mixtures for deconstruction of lignocellulosic biomass. Bioresour Technol 2010, 101:9097-9105.

20. Banerjee G, Car S, Scott-Craig JS, Borrusch MS, Aslam N, Walton JD: Synthetic enzyme mixtures for biomass deconstruction: production and optimization of a core set. Biotechnol Bioeng 2010, 106:707-720.

21. Francocci F, Bastianelli E, Lionetti V, Ferrari S, De Lorenzo G, Bellincampi D, Cervone F: Analysis of pectin mutants and natural accessions of Arabidopsis highlights the impact of de-methyl-esterified homogalacturonan on tissue saccharification. Biotechnol Biofuels 2013, 18:163.

22. Scott-Craig JS, Borrusch MS, Banerjee G, Harvey CM, Walton JD: Biochemical and molecular characterization of secreted a-xylosidase from Aspergillus niger. J Biol Chem 2011, 286:42848-42854.

23. Jabbour D, Borrusch MS, Banerjee G, Walton JD: Enhancement of fermentable sugar yields by a-xylosidase supplementation of commercial cellulases. Biotechnol Biofuels 2013, 6:58.

24. Jungers JM, Fargione JE, Sheaffer CC, Wyse DL, Lehman C: Energy potential of biomass from conservation grasslands in Minnesota. USA. PLOS One 2013, 8:e61209.

25. DeMartini JD, Wyman CE: Composition and hydrothermal pretreatment and enzymatic saccharification performance of grasses and legumes from a mixed-species prairie. Biotechnol Biofuels 2011, 4:52.

26. Adler PR, Sanderson MA, Paul J, Weimer PJ, Vogel KP: Species composition and biofuel yields of conservation grasslands. Ecol Appl 2009, 19:2202-2209.

27. Silverstein RA, Chen Y, Sharma-Shivappa RR, Boyette MD, Osborne J: A comparison of chemical pretreatment methods for improving saccharification of cotton stalks. Bioresource Technol 2007, 98:3000-3011.

28. Boateng AA, Weimer PJ, Jung HG, Lamb JFS: Response of thermochemical and biochemical conversion processes to lignin concentration in alfalfa stems. Energ Fuel 2008, 22:2810-2815.

29. George N, Yang Y, Wang Z, Sharma-Shivappa R, Tungate K: Suitability of canola residue for cellulosic ethanol production. Energ Fuel 2010, 24:4454-4458

30. Ruiz E, Cara C, Manzanares P, Ballesteros M, Castro E: Evaluation of steam explosion pre-treatment for enzymatic hydrolysis of sunflower stalks. Enzyme Microb Tech 2008, 42:160-166.

31. Xu Z, Wang Q, Jiang Z, Yang X, Ji Y: Enzymatic hydrolysis of pretreated soybean straw. Biomass Bioenergy 2007, 31:162-167.

32. liyama K, Lam TBT, Stone BA: Covalent cross-links in the cell wall. Plant Physiol 1994, 104:315-320 
33. Dien BS, Jung HJG, Vogel KP, Casler MD, Lamb JFS, Iten L, Mitchell RB, Sarath G: Chemical composition and response to dilute-acid pretreatment and enzymatic saccharification of alfalfa, reed canarygrass, and switchgrass. Biomass Bioenergy 2006, 30:880-891.

34. McMillan JD, Jennings EW, Mohagheghi A, Zuccarello M: Comparative performance of precommercial cellulases hydrolyzing pretreated corn stover. Biotech Biofuels 2011, 4:29.

35. Balan V, Bals B, Chundawat SPS, Marshall D, Dale BE: Lignocellulosic biomass pretreatment using AFEX. In Biofuels: Methods and Protocols. Edited by Mielenz JR. New York: Humana Press; 2009:61-77.

36. Sluiter A, Hames B, Ruiz R, Scarlata C, Sluiter J, Templeton D, Crocker D: Determination of structural carbohydrates and lignin in biomass (Version 07-08-2011). US Department of Energy National Renewable Energy Laboratory: Golden, CO; 2011.

37. Sekhon RS, Childs KL, Santoro N, Foster CE, Buell CR, de Leon N, Kaeppler SM: Transcriptional and metabolic analysis of senescence induced by preventing pollination in maize. Plant Physiol 2012, 159:1730-1744.

38. Bradford MM: A rapid and sensitive method for the quantitation of microgram quantities of protein utilizing the principle of protein-dye binding. Anal Biochem 1976, 72:248-254.

doi:10.1186/1754-6834-7-52

Cite this article as: Jabbour et al.: Factors contributing to the recalcitrance of herbaceous dicotyledons (forbs) to enzymatic deconstruction. Biotechnology for Biofuels 2014 7:52.

\section{Submit your next manuscript to BioMed Central and take full advantage of:}

- Convenient online submission

- Thorough peer review

- No space constraints or color figure charges

- Immediate publication on acceptance

- Inclusion in PubMed, CAS, Scopus and Google Scholar

- Research which is freely available for redistribution 